\title{
Isolation and Characterisation of Insulin Secretory Granules from a Rat Islet Cell Tumour
}

\author{
J.C.Hutton, E.J.Penn and M.Peshavaria \\ Department of Clinical Biochemistry, University of Cambridge, Addenbrooke's Hospital, Cambridge, UK
}

\begin{abstract}
Summary. Density gradient centrifugation techniques, using iso-osmotic colloidal silica suspensions (Percoll), were developed for the isolation of insulin secretory granules from a transplantable rat islet cell tumour. These procedures were readily completed within $7 \mathrm{~h}$ and from each animal yielded approximately $1 \mathrm{mg}$ of granule protein. The isolated granules were essentially free of other subcellular organelles as evaluated by their contents of marker proteins, electron microscopy and by electrophoretic analyses. Their susceptibilities to lysis at low osmotic strength, at $\mathrm{pH}$ values above 7 or in media containing sodium ions were similar to those of granules partially purified from islets. Insulin comprised $50-60 \%$ of the total
\end{abstract}

granule protein when determined by immunoassay or by densitometry of electrophoretic profiles. The proinsulin content was marginally higher than that of islets, as was the ratio of insulins I to II. Electrophoretic analyses revealed that the secretory granules contained 150 or more proteins besides insulinrelated peptides. The majority of these had acidic isoelectric points and were located both within the granule interior and its enveloping membrane.

Key words: Insulin, proinsulin, granule, vesicle, rat, islet cell tumour, insulinoma, subcellular fractionation, electrophoresis, ultrastructure.
Investigation of the biochemical properties of secretory granules of the pancreatic B cell has been impeded by the small quantity and cellular heterogeneity of material available from pancreatic islets. Moreover, established procedures for the subcellular fractionation of islet tissue [1-3] typically yield granule fractions contaminated with other organelles.

This laboratory is currently investigating a transplantable rat B cell tumour [4] as a model of the secretory process. The tissue has a high insulin content and is available in gram quantities. Tumour cells are well differentiated and closely resemble pancreatic B cells in their ultrastructural and immunochemical staining properties. Glucagon, pancreatic polypeptide, somatostatin, gastrin, neurotensin, vasoactive intestinal polypeptide and B lipotropin have not been detected using immunological techniques in the cell line maintained in our laboratory (T.E.Adrian, S.R.Bloom, I. Doniach, L.H. Rees; personal communications). The tumour releases insulin by a process which is indistinguishable from that in islets [5].

The present communication reports the development of techniques to isolate insulin granules in high yield and purity from this tissue. Electrophoretic analyses of the constituent granule proteins are documented.

\section{Methods}

\section{Assay Procedures}

Insulin was determined by a modification of the back-titration immunoassay procedure of Wright et al. [6]. Samples were solubilised in $50 \mu \mathrm{l}$ of phosphate buffer $(100 \mathrm{mmol} / 1, \mathrm{pH} 7)$ containing Triton X$100(1 \mathrm{~g} / \mathrm{l})$, EDTA $(10 \mathrm{mmol} / 1)$ and bovine serum albumin $(10 \mathrm{~g} / \mathrm{l})$ and then diluted in buffer containing bovine serum albumin alone to an insulin concentration of $0.5-2.5 \mathrm{U} / 1$. Two hundred $\mu$ l of the diluted sample was incubated for $30 \mathrm{~min}$ at $37^{\circ} \mathrm{C}$ with $200 \mu \mathrm{l}$ of the same buffer containing non-immune horse serum $(200 \mathrm{ml} / 1)$ and guinea pig anti-bovine insulin antisera sufficient to bind $5 \mathrm{U} / 1$ of insulin. Buffer $(200 \mu \mathrm{l})$ containing $10^{8} \mathrm{dpm} / 1^{125} \mathrm{I}$-insulin (Amersham International, Amersham, Bucks, UK) and bovine insulin $(7.5 \mathrm{U} / 1)$ was then added and a further incubation performed at room temperature for $30 \mathrm{~min}$. Five hundred $\mu \mathrm{l}$ of $250 \mathrm{~g} / 1$ polyethylene glycol 6000 (Fisons, Loughborough, Leicestershire, UK) was finally added and the samples centrifuged at $4^{\circ} \mathrm{C}$ for $20 \mathrm{~min}$ at $1700 \times \mathrm{g}$. The supernatant was aspirated and the radioactivity of the precipitated immune complex determined with a gamma radiation counter. Rat insulin (Novo, Copenhagen, Denmark) was used as a standard. Proinsulin was determined in the same samples by an indirect two-site immunoradiometric assay [7].

Spectrophotometric assays were performed for aryl sulphatase [8], cytochrome oxidase [9], NADPH-cytochrome c reductase [10], lactate dehydrogenase [11] and catalase [12]. $5^{\prime}$ nucleotidase was determined radiometrically in the presence of $100 \mathrm{mg} / 1$ Lubrol $12 \mathrm{~A} 9$ [13] and DNA was assayed fluorimetrically [14]. Galactosyl transferase activity was determined from the incorporation of $\mathrm{UDP}-\mathrm{U}-{ }^{14} \mathrm{C}$ galactose $(200 \mathrm{mCi} / \mathrm{mmol}$; Amersham) into soya bean trypsin inhibitor (Sigma, Kingston-on-Thames, Surrey, UK) [15]. The reaction was terminated 
by the addition of $200 \mathrm{~g} / 1$ trichloroacetic acid and the precipitated acceptor protein recovered by filtration on cellulose acetate membranes $(0.45 \mu$, type HAWP; Millipore, Bedford, MA, USA). Air-dried membranes were dissolved in $5 \mathrm{ml}$ scintillation counting fluid (cocktail $\mathrm{T}$, Hopkins \& Williams, Chadwell Heath, Essex, UK) and their radioactivities determined by liquid scintillation spectrometry.

Density gradient fractions were usually assayed on the same day without prior removal of the gradient media. At the $\mathrm{pH}$ values used in some methods, the density gradient material (Percoll) precipitated and so was removed by centrifugation immediately before any optical measurement.

Protein was determined in samples precipitated with $50 \mathrm{~g} / 1$ trichloroacetic acid using bovine serum albumin fraction $V$ or bovine insulin as a standard. The method of Lowry et al. [16] was used except when samples contained Percoll, in which instance a fluorimetric procedure was adopted [17]. In this case the pelleted material was dissolved in $50 \mathrm{mmol} / 1$ sodium borate buffer $(1 \mathrm{ml}, \mathrm{pH} 9)$ and $200 \mu \mathrm{lof}$ a solution of fluorescamine ( $300 \mathrm{mg} / 1$ in acetonitrile) added while mixing. The fluorescence at $390 \mathrm{~nm}$ excitation $/ 480 \mathrm{~nm}$ emission was then determined. Percoll itself produced a fluorescence $\leqslant 10 \%$ that of the sample and was corrected for by passing standards through the entire procedure. The Percoll content of each gradient fraction and thence its density was determined from its refractive index.

\section{Ultrastructural Analyses}

Glass haematocrit capillaries were loaded sequentially with $20 \mu \mathrm{flu}-$ orochemical oil (type FC43 Beckman, Palo Alto, California, USA), $40 \mu \mathrm{l}$ of a suspension of subcellular particles in cacodylate buffered paraformaldehyde/glutaraldehyde fixative [18], 2 ul horse serum and $10 \mu \mathrm{l}$ of fixative. The capillary tip at the oil end was heat-sealed leaving an air space of about $15 \mu \mathrm{l}$ and the tube then centrifuged for $4 \mathrm{~min}$ at $10,000 \times g$. The pellicle of particulate material, which was embedded in a serum plug formed at the interface with the oil, was recovered, post-fixed in $\mathrm{OsO}_{4}$ and stained with uranyl acetate and lead citrate by conventional procedures.

\section{Electrophoretic Analyses}

Single dimensional sodium dodecyl sulphate polyacrylamide gel electrophoresis was performed on $19 \%$ slab gels $(1.5 \mathrm{~mm} \times 15 \mathrm{~cm} \times$ $15 \mathrm{~cm}$ ) run in an ammediol-based buffer system [19]. Molecular weight calibration was achieved using phosphorylase $(98,000)$, bovine serum albumin $(68,000)$, ovalbumin $(45,000)$, carbonic anhydrase $(31,000)$, chicken gizzard myosin light chain $(20,000)$, myoglobin $(17,000)$, cytochrome $\mathrm{c}(12,000)$ bovine pancreatic trypsin inhibitor $(7,000)$ and mixed $A$ and $B$ chains of bovine insulin $(3,000 \mathrm{~mol}$. wt.). Samples were suspended in ammediol $\mathrm{Cl}$ buffer $(100 \mathrm{mmol} / \mathrm{l}$, $\mathrm{pH} 8.4)$ containing sodium dodecyl sulphate $(10 \mathrm{~g} / \mathrm{l})$, dithiothreitol $(10 \mathrm{mmol} / \mathrm{l})$, EDTA $(5 \mathrm{mmol} / 1)$, sucrose $(250 \mathrm{mmol} / 1)$ and bromophenol blue $(20 \mathrm{mg} / \mathrm{l})$, heated for $5 \mathrm{~min}$ at $100{ }^{\circ} \mathrm{C}$, centrifuged for $5 \mathrm{~min}$ at $9,000 \times g$ and the supernatant loaded onto the gel.

Two dimensional electrophoretic separations were achieved by isoelectric focussing of samples in the first dimension using $\mathrm{pH}$ 3.5-10 ampholytes (LKB, Stockholm, Sweden) followed by sodium dodecyl sulphate polyacrylamide gel electrophoresis in the second dimension on a linear $10-20 \%$ gradient gel run in a Tris- $\mathrm{HCl}$ based buffer system [20]. Samples were prepared as above but using N-ethylmorpholine acetate $(50 \mathrm{mmol} / \mathrm{l}, \mathrm{pH} 8.5)$ instead of ammediol as the buffer.

All gels were fixed in a $50 \mathrm{~g} / 1$ trichloroacetic acid solution in $20 \%$ methanol and stained with Kenacid blue R (British Drug Houses, Poole, Dorset, UK).

\section{Granule Preparation}

Islet cell tumours were propagated in $200 \mathrm{~g}$ body weight mixed sex $\mathrm{NEDH}$ rats fed ad libitum as described previously [21]. The fibrous capsule of each tumour was removed, the tissue chopped into 1-2 mm fragments and rinsed in Hank's saline then in the homogenisation medium. All subsequent steps were performed at $4{ }^{\circ} \mathrm{C}$ unless specified. Tissue from 5-30 animals (2.5-15 $\mathrm{g}$ wet weight) was homogenised in a Potter homogeniser $(2.5 \mathrm{~cm}$ diameter) with six strokes of a close fitting teflon pestle driven at $600 \mathrm{rev} / \mathrm{min}$. The media $(5 \mathrm{ml} / \mathrm{g}$ tissue) contained sucrose $(275 \mathrm{mmol} / \mathrm{l}), 2$ [ $\mathrm{N}$-morpholino]ethanesulphonic acid $(10 \mathrm{mmol} / \mathrm{l})$ and EGTA $(1 \mathrm{mmol} / \mathrm{l})$ and was adjusted to $\mathrm{pH} 6.5$ with Tris base. The homogenate was centrifuged for $10 \mathrm{~min}$ at $1700 \times \mathrm{g}$ to remove unbroken cells and nuclei. The efficiency of homogenisation as judged from the release into the supernatant of lactate dehydrogenase was $85.7 \pm 3.8 \%(n=6)$. The majority of the tissue DNA $(90.5$ $\pm 7.4 \%, n=4$ ) was pelleted at this stage.

\section{Density Gradient Centrifugation}

Aliquots $(10 \mathrm{ml})$ of the above supernatant were layered onto $26 \mathrm{ml}$ of homogenisation media supplemented with $270 \mathrm{ml} / 1$ Percoll (Pharmacia, Stockholm, Sweden) contained in polypropylene centrifuge tubes $(8.5 \mathrm{~cm} \times 2.5 \mathrm{~cm})$. After centrifugation for $45 \mathrm{~min}$ at $35,000 \times \mathrm{g}$ in a Beckman type 30 rotor, the resulting gradient was distributed into 24 tubes using a peristaltic pump. The material in the major insulincontaining fractions of two such gradients (peak I, Fig.1) was dispersed in homogenisation media $(37 \mathrm{ml})$ containing $420 \mathrm{ml} / 1$ Percoll and centrifuged under the same conditions.

Percoll contained in density gradient fractions was subsequently removed by diluting pooled fractions fivefold in homogenisation media and centrifuging for $15 \mathrm{~min}$ at $20,000 \times \mathrm{g}$ in a Beckman SW 27.1 rotor. The particulate material which sedimented was transferred to another tube and subjected to three further cycles of resuspension and centrifugation. The final pellet was suspended in homogenisation media without EGTA at a protein concentration of $10 \mathrm{mg} / \mathrm{ml}$ and either kept at $4{ }^{\circ} \mathrm{C}$ until use or stored at $-70^{\circ} \mathrm{C}$.

\section{Lysis Experiments}

Freshly-prepared granules $(0.1 \mathrm{mg}$ protein $/ \mathrm{ml})$ were incubated for $30 \mathrm{~min}$ at $37^{\circ} \mathrm{C}$ in $500 \mathrm{ul}$ of media which contained EGTA $(1 \mathrm{mmol} / \mathrm{l})$ and $2[\mathrm{~N}$-morpholino]ethanesulphonic acid $(10 \mathrm{mmol} / \mathrm{l})$ adjusted to the desired $\mathrm{pH}$ with Tris, together with varying concentrations of other salts and sucrose as described in Figure 3. The media was then centrifuged for $10 \mathrm{~min}$ at $25,000 \times \mathrm{g}$ in a Beckman type sw 50.1 rotor and the insulin content of the supernatant fluid determined.

\section{Granule Subfractionation}

Granules ( $4 \mathrm{mg} / \mathrm{ml}$ protein) were subjected to hypo-osmotic lysis in ammonium carbonate buffer $(50 \mathrm{mmol} / \mathrm{l}, \mathrm{pH}$ 9) containing EDTA $(5 \mathrm{mmol} / \mathrm{l})$ and separated into a soluble and membrane fraction by centrifugation for $30 \mathrm{~min}$ at $100,000 \times \mathrm{g}$ in a Beckman type sw 50.1 rotor. The pelleted material was washed twice in the same buffer. The soluble material was further fractionated by acidifying with acetic acid to $\mathrm{pH} 5.3$ (the $\mathrm{pI}$ of insulin) and centrifuging as before. Approximately $10 \%$ of the initial protein was recovered in the membrane pellet, $30 \%$ in the final supernatant and $60 \%$ in material precipitated at $\mathrm{pH}$ 5.3.

\section{Results}

\section{Granule Preparation}

The initial density gradient centrifugation of the nuclei and cell-free homogenate of the tumour resulted in the separation of four discernible bands of turbidity corresponding to the four zones designated I, II, III and IV in Figure 1. These bands were coloured white, yellow, 

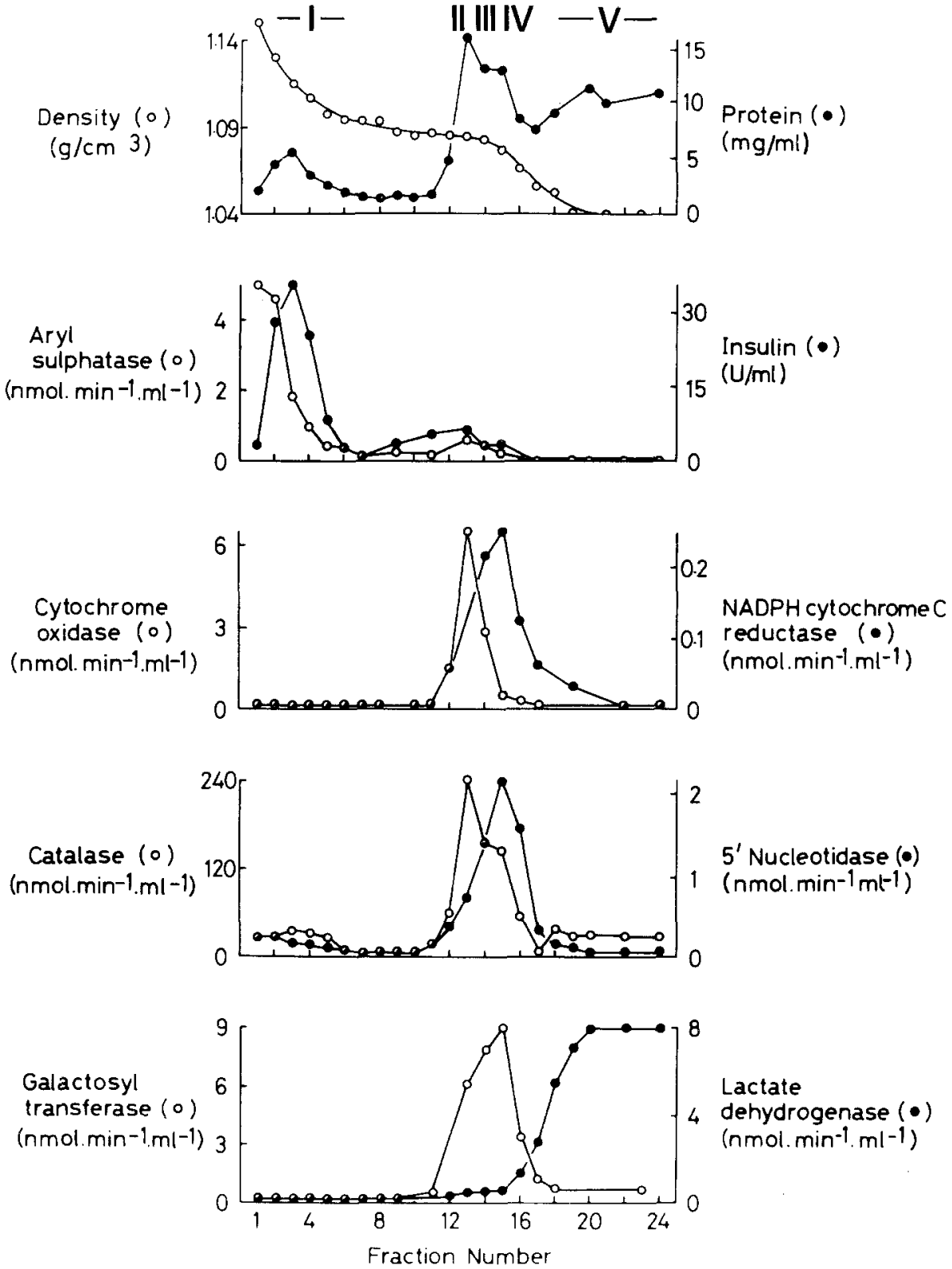

Fig. 1. First density gradient centrifugation. Tumour homogenate was centrifuged to remove nuclei and unbroken cells and then layered on media containing Percoll $(270 \mathrm{ml} / \mathrm{l})$ in the region designated $\mathrm{V}$

orange and pink respectively and corresponded to the maximal activities of marker proteins for the insulin granule (insulin), mitochondria (cytochrome oxidase), endoplasmic reticulum (NADPH-cytochrome $c$ reductase) and plasma membrane (5' nucleotidase) respectively. The peroxisomal marker (catalase) and Golgi body marker (galactosyl transferase) were also found principally in zone III. Lysosomes as revealed by the distribution of aryl sulphatase were more dense than insulin granules and not associated with visible banding or a protein peak on the gradient. Other marker proteins which were determined over the course of different experiments included succinate dehydrogenase (mitochondria), acid phosphatase and $\mathrm{N}$-acetylglucosaminidase (lysosomes), glucose 6-phosphatase (endoplasmic reticulum) and proinsulin (secretory granules). Their distribution did not vary significantly from the corre- sponding marker proteins shown in Figure 1 (unpublished findings).

When the insulin granule-enriched fraction obtained from this gradient was subjected to further gradient centrifugation in Percoll media of a higher initial density, two broad overlapping zones of turbidity were observed. These coincided with the distribution of protein and insulin (Fig. 2). The lysosomal marker aryl sulphatase was found principally in a region of high density where little protein was present. Residual cytochrome oxidase activity appeared at a lower density. Residual 5' nucleotidase activity was distributed in a manner suggestive of a combined association with both granules and lysosomes. Markers for other subcellular organelles shown in Figure 1 could not be detected. The specific activity of insulin did not vary across the gradient in the fractions in which it could be reliably estimated. This 

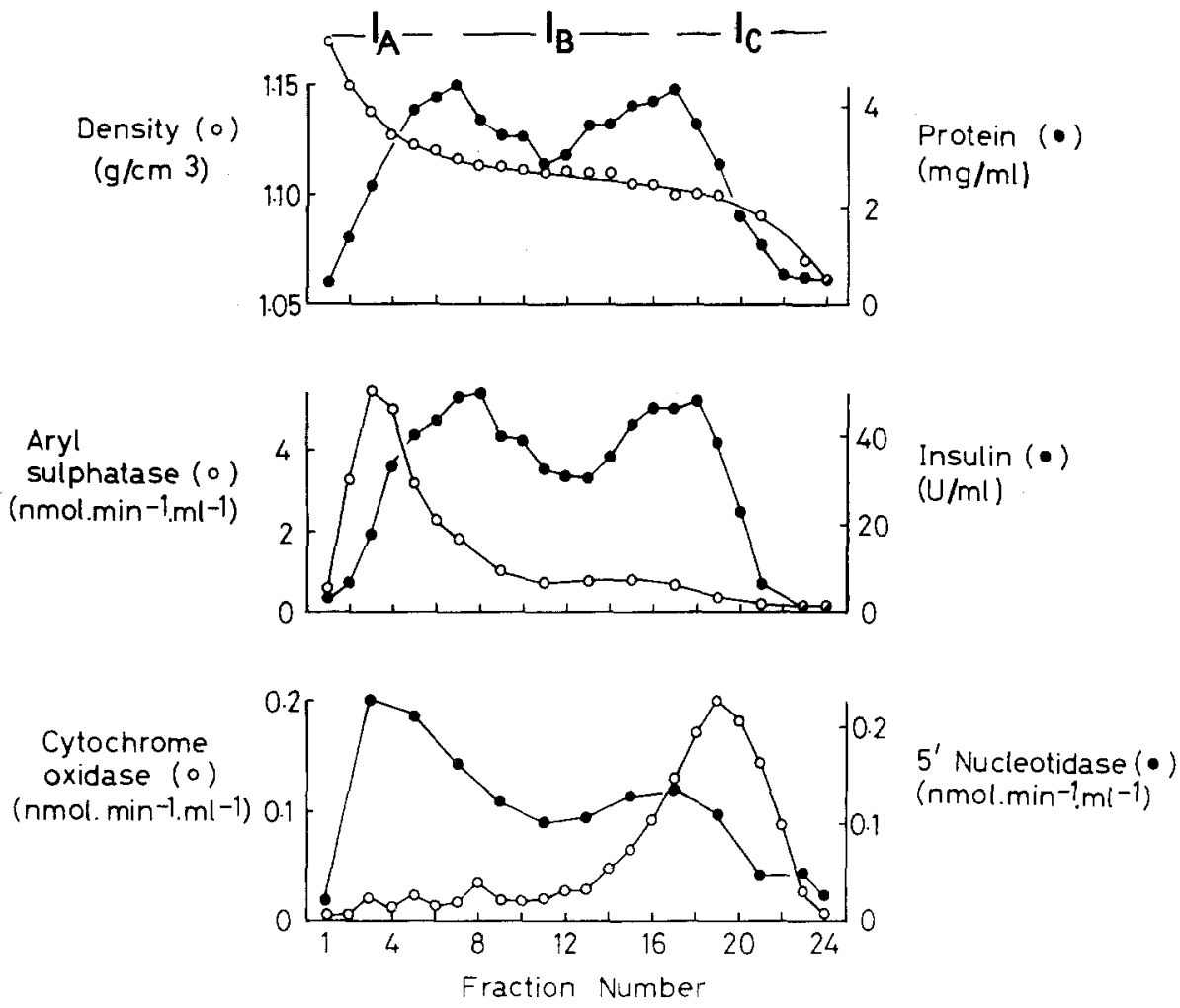

Fig. 2. Second density gradient centrifugation. Material from the first density gradient containing the majority of the tissue insulin (zone II, Fig. 1) was resuspended in media initially containing Percoll $(420 \mathrm{ml} / \mathrm{l})$
Table 1. Recoveries of marker proteins in isolated granules

\begin{tabular}{|c|c|c|c|c|}
\hline Marker & $\begin{array}{l}\text { Initial } \\
\text { homogenate }\end{array}$ & $\begin{array}{l}\text { Isolated } \\
\text { granules }\end{array}$ & $\begin{array}{l}\text { Yield } \\
(\%)\end{array}$ & $\begin{array}{l}\text { Relative } \\
\text { specific } \\
\text { activity }\end{array}$ \\
\hline $\begin{array}{l}\text { Insulin } \\
\text { (U/mg protein) }\end{array}$ & $0.71 \pm 0.11$ & $14.5 \pm 0.8$ & $27.6 \pm 3.8$ & 20.4 \\
\hline $\begin{array}{l}\text { Aryl } \\
\text { sulphatase } \\
\left(\text { nmol } \cdot \min ^{-1} \cdot \mathrm{mg}^{-1}\right)\end{array}$ & $77.4 \pm 12.5$ & $714.3 \pm 38.4$ & $12.2 \pm 1.4$ & 9.2 \\
\hline $\begin{array}{l}\text { Cytochrome } \\
\text { oxidase } \\
\left(\text { (nmol } \cdot \min ^{-1} \cdot \mathrm{mg}^{-1}\right)\end{array}$ & $67.5 \pm 4.1$ & $23.4 \pm 6.2$ & $0.5 \pm 0.2$ & 0.3 \\
\hline $\begin{array}{l}\text { NADPH- } \\
\text { cytochrome C } \\
\text { reductase } \\
\left(\mathrm{nmol} \cdot \mathrm{min}^{-1} \cdot \mathrm{mg}^{-1}\right)\end{array}$ & $4.1 \pm 0.5$ & $1.6 \pm 1.0$ & $0.5 \pm 0.2$ & 0.4 \\
\hline $\begin{array}{l}\text { Catalase } \\
\left(\mu \mathrm{mol} \cdot \min ^{-1} \cdot \mathrm{mg}^{-1}\right)\end{array}$ & $5.6 \pm 0.5$ & $29.1 \pm 3.8$ & $6.9 \pm 1.2$ & 5.2 \\
\hline $\begin{array}{l}5^{\prime} \text { nucleotidase } \\
\left(\mathrm{nmol} \cdot \mathrm{min}^{-1} \cdot \mathrm{mg}^{-1}\right)\end{array}$ & $51.0 \pm 6.3$ & $7.6 \pm 0.7$ & $1.9 \pm 0.2$ & 0.2 \\
\hline $\begin{array}{l}\text { Lactate } \\
\text { dehydrogenase } \\
\left(\mathrm{nmol} \cdot \mathrm{min}^{-1} \cdot \mathrm{mg}^{-1}\right)\end{array}$ & $144.1 \pm 31.2$ & $28.3 \pm 1.9$ & $0.3 \pm 0.1$ & 0.2 \\
\hline
\end{tabular}

Each tabulated value is the mean \pm SEM of results obtained in five different preparations. The percentage of the initial activity of each marker recovered in the final granule pellet is shown as the yield. Protein recovered in the granule fraction was $1.8 \pm 0.2 \%$ of the initial homogenate value. The relative specific activity is calculated as the ratio of the final to the initial specific activity.

contrasted with the highly variable specific activity of the other marker proteins and suggested that insulin granules were the predominant particles in all fractions.

The bimodality of insulin distribution on this gradient did not reflect the existence of two granule populations but was the product of the sigmoidal density profile, there being concentration of material in the regions of a steeper gradient. The distribution of insulin calculated as a function of a linear increment in density suggested the presence of a single population with a mean density of $1.10 \mathrm{~g} / \mathrm{l}$. Fractions comprising zone IB (Fig. 2) were usually recovered for experiments requiring large quantities of granules. The final yields and specific activities of the marker proteins in this fraction are shown in Table 1.

\section{Characterisation of the Granule Fraction}

Granules isolated as above were subjected to further isopycnic gradient centrifugation on either a linear $25-50 \%$ by weight sucrose or a linear $150-300 \mathrm{~g} / 1$ urograffin (Schering AG, Berlin, FRG) gradient. The insulin and protein co-migrated as a single band in both cases with apparent densities of 1.20 and 1.14 respectively. The specific activity of insulin and electrophoretic profiles were unchanged in comparison with the material initially loaded. Further separation of insulin from residual aryl sulphatase and cytochrome oxidase was not afforded by these procedures (unpublished findings).

\section{Electron Microscopy}

Electron microscopy of the granule fraction that was used in most subsequent experiments (zone IB; Fig. 2), showed the presence of granules of a size and morphology typical of the B cell (Fig. $3 \mathrm{a}$ ). The central electrondense core of these ranged in appearance from a diffuse 


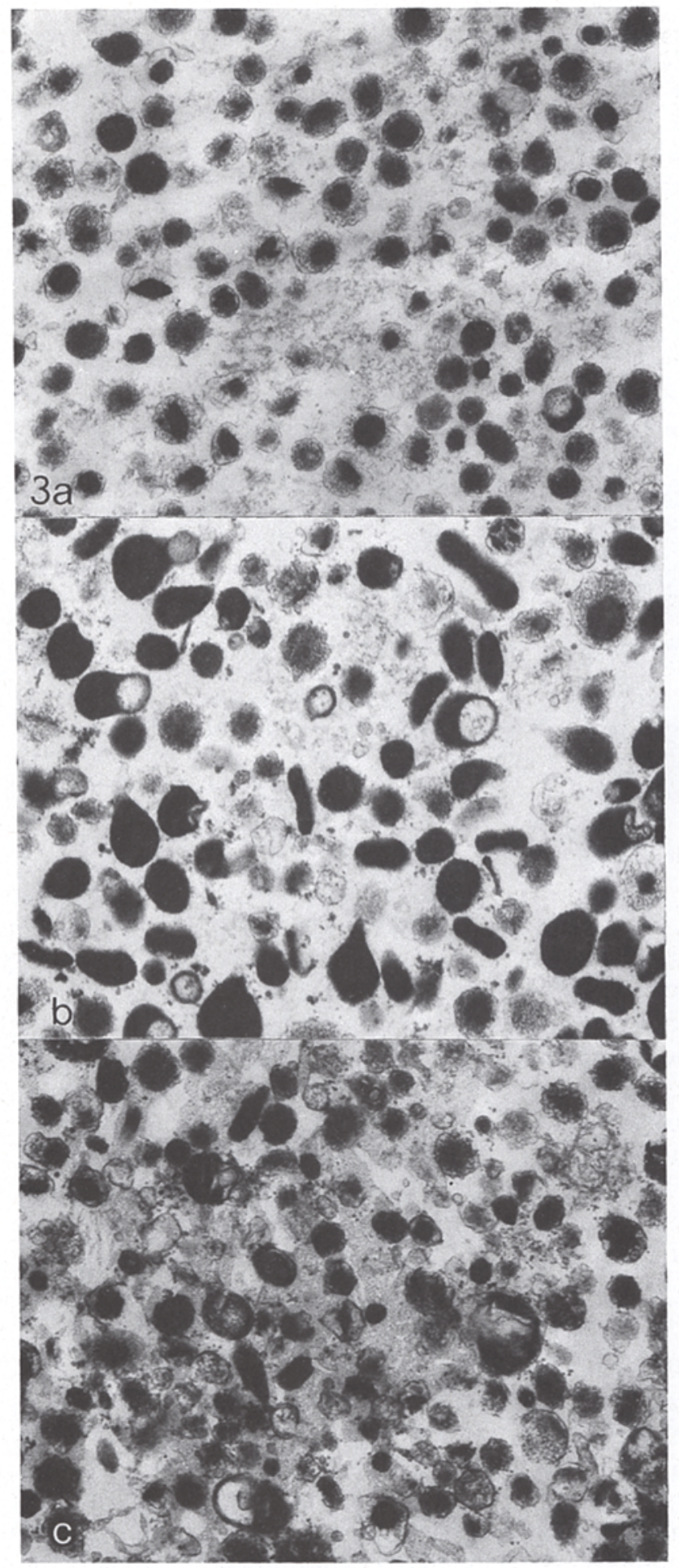

Fig. 3a-c. Electron micrographs of isolated granule fractions. a Purified granule fraction (zone IB, Fig. 2 ); $\times 22,400$. b High density granule fraction (zone IA, Fig. 2) containing substantial lysosomal contamination; $\times 22,400$. $c$ Low density granule fraction (zone IC, Fig. 2 ) containing substantial contamination with mitochondrial and other membranes; $\times 22,400$

to a crystalline structure. A bilaminar membrane was associated with most granules.

Contamination of the granule fraction with other subcellular organelles was low, consisting of mitochondrial membrane fragments and lysosomes, the latter
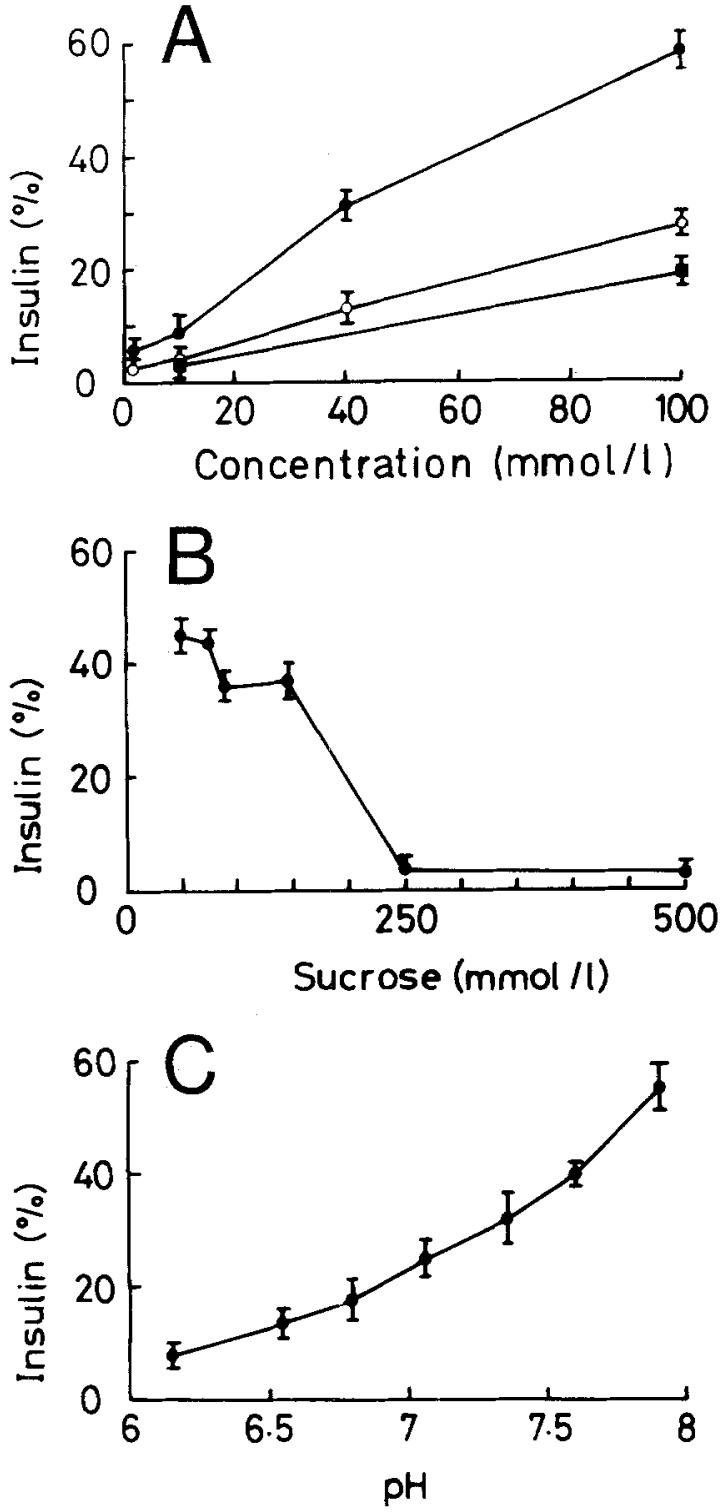

Fig.4a-c. Granule lysis experiments. The supernatant insulin content is expressed as a percentage of that initially present in each tube. Each value is the mean \pm SEM of results obtained with three different granule preparations incubated for $30 \mathrm{~min}$ at $37^{\circ} \mathrm{C}$ A Sodium sulphate $(\mathbf{O})$, potassium sulphate $(O)$ or Tris sulphate $(\boldsymbol{\square})$ were added in iso-osmotic replacement of sucrose. The final $\mathrm{pH}$ was 6.5 . B Reduction of the sucrose concentration of the media was made as indicated. The final $\mathrm{pH}$ was 6.5 . C Media containing $0.25 \mathrm{~mol} / 1$ sucrose was adjusted to the designated $\mathrm{pH}$ value with Tris

sometimes incorporating granule elements. Fraction IA (Figs. 2 and $3 \mathrm{~b}$ ) as expected from enzymic markers was contaminated with lysosomes, and fraction IC (Figs.2 and $3 \mathrm{c}$ ) with mitochondrial and other membrane elements. Some remaining Percoll particles were also evident in all fractions.

\section{Lysis Experiments}

Isolated granules incubated at $\mathrm{pH} 6.5$ for $30 \mathrm{~min}$ at $37^{\circ} \mathrm{C}$ released $14.3 \pm 2.0 \%(n=3)$ of their insulin con- 


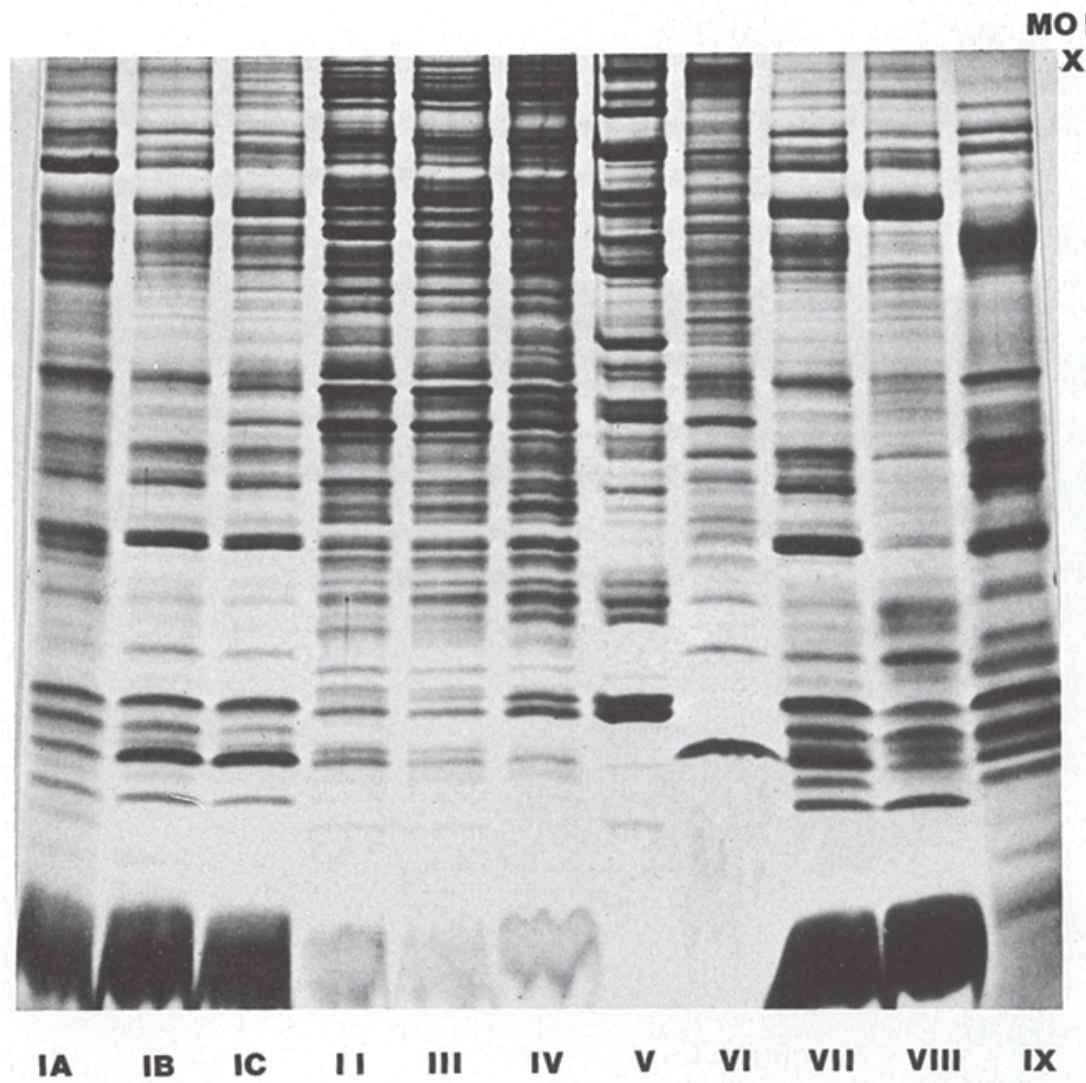

MOL. WT.
$\times 10^{-3}$
98

68

45

31

20

Sodium dodecyl sulphate polyacrylamide gel electrophoresis of subcellular fractions. Lanes designated IA, IB, IC, II, III, IV and V represent material from identically labelled zones on the density gradients shown in Figs. 1 and 2. Lane VI represents granule membranes, and lane VII soluble material prepared from isolated granules at pH 9. Lane VIII was material precipitated from the soluble fraction by adjustment of the $\mathrm{pH}$ to 5.3 and lane IX the material still remaining in solution. Approximately $50 \mu \mathrm{g}$ of protein was loaded in each case. The mol. wt. scale was deduced from the mobilities of marker proteins run on the same gel
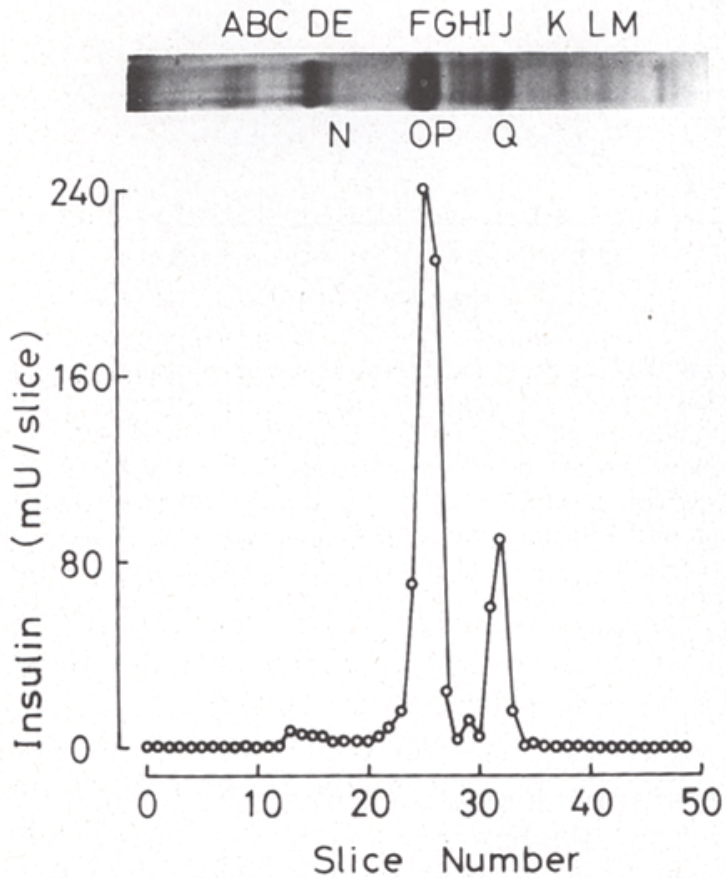

Fig.6. Non-denaturing polyacrylamide gel electrophoresis of granules. Gel tracks were stained (insert) or sliced in $2.1 \mathrm{~mm}$ pieces and then subjected either to immunoassay or sodium dodecyl sulphate polyacrylamide gel electrophoresis. The latter process resolved peptides of the following mol. wt.: A 6,500; B 7,200; C 8,000; D and E $8,000,21,000$ and 22,$000 ; \mathrm{F} 3,000,5,500$ and 8,$500 ; \mathrm{G} 11,000 ; \mathrm{H} 8,500$; I 25,000; J 3,000; K 11,000; L 11,000 and 15,000 and M 12,500. The positions of migration of proinsulin ( $N$ and $P$ ) and insulin ( $O$ and $Q$ ) which were purified from the tumour are shown tent into the medium compared with $4.9 \pm 2.1 \%(n=3)$ from granules maintained at $4{ }^{\circ} \mathrm{C}$ for the same interval. Complete solubilisation occurred in media containing the detergent Triton X-100 (1 g/l). Granule fragility assessed by this method was also markedly increased by iso-osmotic replacement of sucrose by sodium sulphate and to a lesser extent by potassium or Tris sulphate (Fig. 4a). Incubation at pH values above 7 (Fig. 4b) and hypo-osmotic incubation (Fig. $4 \mathrm{c}$ ) also caused release into the media.

\section{Polyacrylamide Gel Electrophoresis}

Insulin was the dominant protein in electrophoretograms of granule fractions on sodium dodecyl sulphate polyacrylamide gels (Fig.5). Densitometric quantification of the protein band corresponding to mixed insulin $A$ and $B$ chains showed it to be $50-60 \%$ of the total stained material, a value consistent with the observed insulin specific activity of the granule fraction (Table 1) given a theoretical maximal specific activity of $25 \mathrm{U} / \mathrm{mg}$ protein. A band co-migrating with beef and porcine proinsulins on these gels constituted $5-10 \%$ of the insulin content as assessed by densitometry, a value lower than that derived from radioimmunoassays $(27 \pm 2 \%$, $n=7$ ). This difference was probably due to the presence within the granule of conversion intermediates which would have been detected in the latter analysis.

Apart from insulin-related peptides, a large number of other proteins were evident in granule fractions vary- 


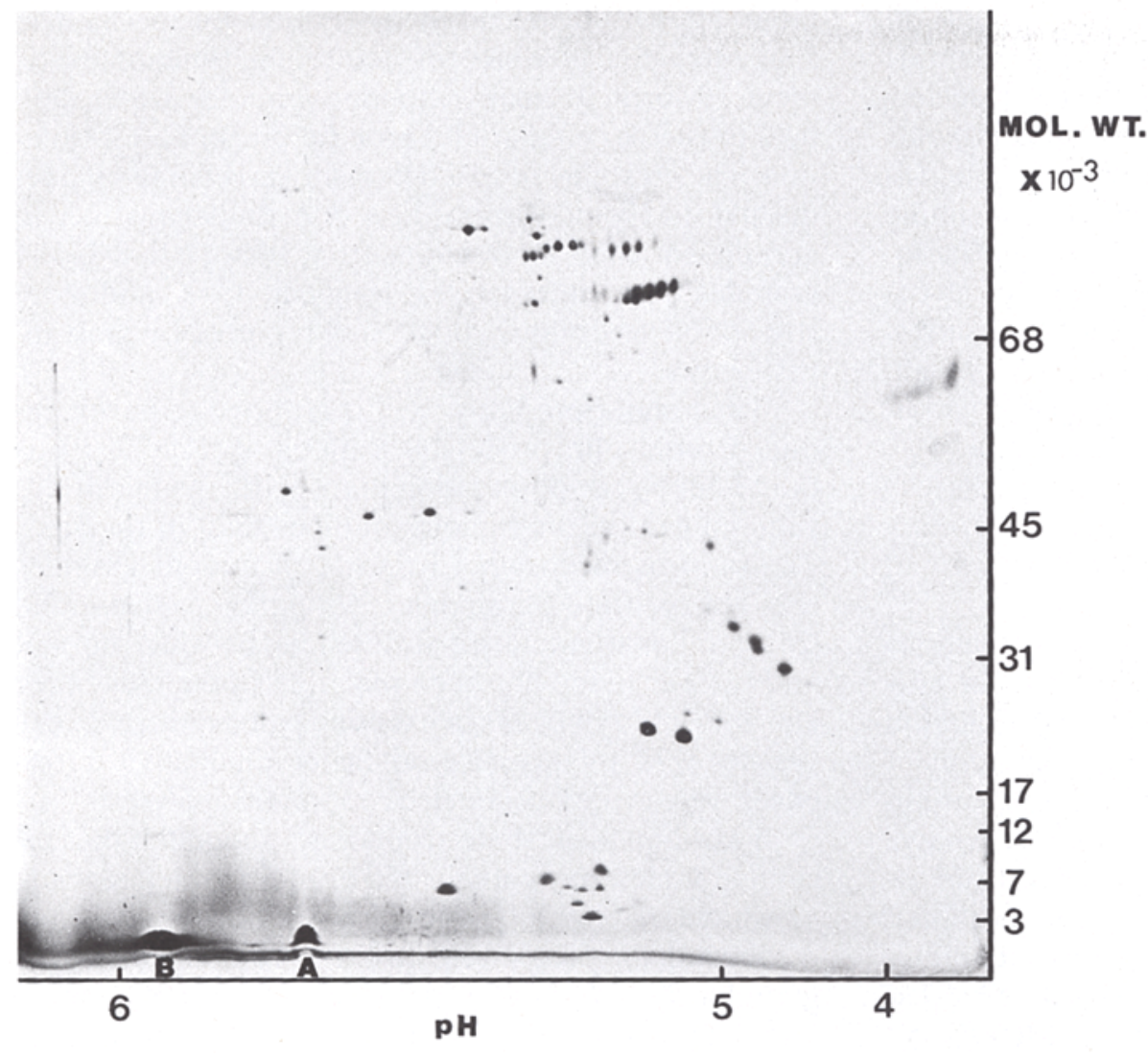

Fig. 7. Two dimensional polyacrylamide gel electrophoresis of granules. The granule sample derived from zone IB (Fig. 2) was subjected to isoelectric focussing in the first dimension ( $\mathrm{X}$ axis) and in the second dimension to sodium dodecyl sulphate polyacrylamide gel electrophoresis. The migration of insulin A and B chains are indicated. The approximate $\mathrm{pH}$ and mol. wt. scales were derived from gels run in parallel ing in quantity from $1-10 \%$ of the insulin content. These were not attributable to contamination since no major protein was found in a disproportionately greater quantity in another tissue fraction (Fig. 5). The insulinrich fractions which were discarded (fractions IA and IC, Fig. 2) contained additional protein bands consistent with the presence of lysosomes in fraction IA and contamination of fraction IC with peptides seen predominantly in a mitochondrial-rich region of the initial density gradient (zone II; Fig.1).

The soluble subfraction of granules prepared at pH 9 showed, besides insulin, 25 other components including several peptides in the 5-15,000 mol. wt. range, a doublet band at 21,000 mol. wt. and other major constituents with mol. wts. of $26,000,28,000,31,000$ and 60,000 . Adjustment of the $\mathrm{pH}$ of this subfraction to 5.3 resulted in the precipitation of insulin together with several other proteins. This further fractionation procedure permitted visualisation of minor soluble components. Electrophoresis of the granule membrane fraction revealed a large number of proteins of a broad mol. wt. range.

Polyacrylamide gel electrophoresis of granules under non-denaturing conditions at pH 9 (Fig. 6), showed the presence of two dominant bands corresponding in mobilities to rat insulin I and II standards. Such gels were cut into $2.1 \mathrm{~mm}$ pieces which were equilibrated for 2 days at $4{ }^{\circ} \mathrm{C}$ in phosphate buffer $(100 \mathrm{mmol} / 1, \mathrm{pH} 7)$ containing sodium azide $(1 \mathrm{~g} / \mathrm{l})$ and bovine serum albu- $\min (1 \mathrm{~g} / \mathrm{l})$. Immunoassay of the eluted fractions revealed two major components corresponding to rat insulin I $(67.7 \pm 2.6 \%)$ and rat insulin II $(26.9 \pm 2.4 \%$, $n=3)$.

The apparent molecular sizes of the other components seen in such electrophoretograms were determined by equilibrating gel slices in the sodium dodecyl sulphate polyacrylamide gel electrophoresis sample buffer and electrophoresing them on the sodium dodecyl sulphate polyacrylamide gel electrophoresis system. The majority of peptides so revealed were within the the $5-15,000$ mol. wt. range (Fig. 6 legend). Most of the proteins from which these components were derived did not display significant insulin immunoreactivity with the exception of one of 8000 mol. wt. which migrated in both electrophoresis systems in a manner similar to rat proinsulin I prepared from whole tumours.

Two dimensional gel electrophoresis of isolated granules revealed the presence of 18 major, 60 minor and 70 faintly perceptible components (Fig. 7). The majority of constituents possessed acidic isoelectric points. Insulin was resolved into two major spots, one corresponding to the A chain common to rat insulins I and II and the other to the two different $B$ chains which were poorly resolved in this system. The bands prominent in the 5-15,000 mol. wt. region on single dimensional sodium dodecyl sulphate polyacrylamide gels (Fig.5) resolved into seven major acidic components with similar isoelectric points and a single, more basic, peptide. A 
major doublet band at 21,000 mol. wt. seen on single dimensional sodium dodecyl sulphate polyacrylamide gels resolved into two major spots with similar isoelectric points. Some of the higher molecular weight bands which migrated diffusely on single dimensional analysis appeared as a string of closely spaced spots inclining toward higher molecular weights and more acidic isoelectric points. This phenomenon is a feature of glycoproteins in such two dimensional analyses and is attributable to small changes in charge and molecular weight resulting from the addition of successive acidic carbohydrate residues.

\section{Discussion}

The preparation of insulin secretory granule fractions from mammalian pancreatic islets has in most investigations relied solely upon differential centrifugation procedures. Although adequate for the separation of granules from nuclei, cystolic proteins and to a certain extent mitochondria, these procedures fail to resolve granules from lysosomes and vesicles formed from internal membranes during homogenisation. Additional use of sucrose density gradients and phase separation techniques have succeeded in producing only a limited improvement in granule purity with a considerable reduction in yield $[1,3]$. Such techniques applied to tumour tissue were similarly unsuccessful. Tumour granules behaved identically to those of islets with respect to their sedimentation behaviour on differential centrifugation and their buoyant density on sucrose gradients.

A density gradient procedure using colloidal silica particles met with considerable success in the subcellular fractionation of the tumour tissue. This success was attributed to the ability, using Percoll, to maintain isoosmolarity and thus separate subcellular elements on the basis of their native buoyant densities. Using the technique described, approximately $5-20 \mathrm{mg}$ of purified granules could be obtained within $7 \mathrm{~h}$, a situation which permitted experiments in vitro to be conducted on the same day.

The granules isolated were essentially free from contamination by other subcellular organelles as assessed by marker proteins, ultrastructure and electrophoretic analyses. Part of the lysosomal contamination which was evident was apparently due to crinophagy. A further element may be related to the presence in the granule of lysosomal-like enzymic activities [22, 23]. For most purposes the residual presence of lysosomal proteins was unimportant since they contributed little to the total protein in isolated granule fractions. Granules with a lesser contamination could also be prepared using select gradient fractions albeit with a low final yield.

A particular concern in investigations of the biochemical properties of insulin secretory vesicles from a tumour source is their relatedness to granules of the normal B cell. As in islets, insulin secretion by the tu- mour appears to occur by an exocytotic mechanism suggesting the presence of equivalent functional elements. Morphologically, tumour granules were identical to islet B cell granules both before and after isolation. They responded to a detergent and changes in media $\mathrm{pH}$ and ionic composition in a similar manner to granule-enriched subfractions from islets $[1,2,24]$. The granules were, however, less fragile at $37^{\circ} \mathrm{C}$ and more susceptible to osmotic shock than reported by most investigators.

The tumour presently used is reported to have a reduced proinsulin processing capability [25]. This was borne out by the observation of a slightly higher proinsulin content in the tumour granules than in rat islets. The ratio of rat insulins I and II in tumour granules (2.57) also differed from that reported in rat islets $(1.38)$ [26]. Similar quantitative differences between normal and tumour tissue has been recorded in the content of enzymes and zymogens in exocrine pancreatic secretory vesicles [27]. In this case no major qualitative differences were evident from electrophoretic analyses.

Two dimensional electrophoresis suggested that insulin granules may contain 150 or more proteins, many of which were readily solubilised in aqueous alkaline media and, therefore, were probably components of the granule core or loosely associated with the granule membrane. Such proteins are conceivably co-secreted with insulin. Some of these proteins were presumably intermediates of the processing of proinsulin, although many were of a larger molecular size than preproinsulin $(12,400 \mathrm{~mol}$. wt.). The majority of the smaller peptides which were separated by electrophoresis under non-denaturing conditions, furthermore, did not cross-react with anti-insulin antisera.

The large number of proteins present in the insulin granule membrane presumably reflects a diversity of biochemical processes. Some of these properties, like the ability to accumulate protons [28, 29], $\mathrm{Ca}^{2+}[30]$ and amines [31] are found in other granule types such as that of the chromaffin cell of the adrenal medulla. No striking similarities, however, were evident between the observed spectrum of proteins in the insulin granule membrane and that published for the chromaffin granule [32].

The present techniques provide an opportunity to study the functional properties of the B cell granule and yield sufficient material for small-scale purification of proteins from this source. The procedures also furnish a defined subcellular component suitable for studies in vitro of the molecular events of exocytosis.

Acknowledgements. These studies were supported by grants from the Medical Research Council and British Diabetic Association to Professor C.N.Hales. JCH received support from the National Health and Medical Research Council of Australia and British Insulin Manufacturers and EJP from a MRC studentship. Dr. O.M.Gibby is thanked for conducting proinsulin assays and Mr. G. Gatward and Dr. P. Wooding for assistance in ultrastructural studies. 


\section{References}

1. Coore HG, Hellman B, Pihl E, Taljedal I-B (1969) Physicochemical characteristics of insulin secretion granules. Biochem $\mathbf{J} 111$ : $107-113$

2. Howell SL, Young DA, Lacy PE (1969) Isolation and properties of secretory granules from rat islets of Langerhans. III: Studies of the stability of the isolated beta granules. J Cell Biol 41: 167-176

3. Kemmler W, Steiner DF, Borg J (1973) Studies on the conversion of proinsulin to insulin. Studies in vitro with a crude secretion granule fraction isolated from rat islets of Langerhans. $\mathbf{J}$ Biol Chem 248: 4544-4551

4. Chick WL, Warren S, Chute RN, Like AA, Lauris V, Kitchen KC (1977) A transplantable insulinoma in the rat. Proc Natl Acad Sci USA 74: 628-632

5. Sopwith AM, Hutton JC, Naber SP, Chick WL, Hales CN (1981) Insulin secretion by a transplantable rat islet cell tumour. Diabetologia 21: 224-229

6. Wright PH, Makulu DR, Malaisse WJ, Roberts NM, Yu P-L (1968) A method for the immunoassay of insulin. Diabetes 17: $537-546$

7. Yue DK, Gibby OM, Luzio SD, Yanaihara N, Hales CN (1979) Indirect two-site immunoradiometric assay of rat and mouse proinsulin. Diabetologia 17: 235-242

8. Roy AB (1953) The sulphatase of ox liver. 1. The complex nature of the enzyme. Biochem J 53:12-15

9. Cooperstein SJ, Lazarow A (1951) A microspectrophotometric method for the determination of cytochrome oxidase. J Biol Chem 189: 665-670

10. Sottocasa GL, Kuylenstierna B, Ernster L, Bergstrand A (1967) An electron transport system associated with the outer membrane of liver mitochondria. A biochemical and morphological study. J Cell Biol 32: 415-438

11. Nielands JB (1955) Lactic dehydrogenase of heart muscle. Meth Enzymol 1: $449-454$

12. Beers RF, Sizer IW (1952) A spectrophotometric method for measuring the breakdown of hydrogen peroxide by catalase. J Biol Chem 195: 133-140

13. Avruch J, Wallach DFH (1971) Preparation and properties of plasma membrane and endoplasmic reticulum fragments from isolated rat fat cells. Biochim Biophys Acta 223: 334-347

14. Kissane JM, Robins E (1958) Fluorimetric measurement of deoxyribonucleic acid in animal tissues with special reference to the central nervous system. J Biol Chem 233: 184-188

15. Bretz R, Staubli W (1977) Detergent influence on rat liver galactosyltransferase activities towards different acceptors. Eur J Biochem 77:181-192

16. Lowry OH, Rosebrough NJ, Farr AL, Randall RJ (1951) Protein measurement with the Folin phenol reagent. J Biol Chem 193: $265-275$

17. Udenfriend S, Stein S, Bohlen P, Dairman W, Leimgruber W, Weigele M (1972) Applications of Fluorescamine, a new reagent for assay of amino acids, peptides, proteins and other primary amines in the picomole range. Science 178: 871

18. Glauert AM (1975) Fixation, dehydration and embedding of biological specimens. North Holland, Amsterdam
19. Wyckoff M, Rodbard A, Chranbach A (1977) Polyacrylamide gel electrophoresis in sodium dodecyl sulphate containing buffers using multiphasic buffer systems: Properties of the stack, valid Rf measurement and optimised procedure. Anal Biochem 78: 459-482

20. Anderson NG, Anderson NL, Tollaksen SL (1979) Operation of the isodalt system. Publication (ANL-BIM-79-2), Division of Biom logical and Medical Research, Argonne National Laboratory, Argonne, IL, USA

21. Hutton JC, Penn EJ, Jackson PJ, Hales CN (1981) Isolation and characterisation of calmodulin from an insulin-secreting tumour. Biochem J 193: 875-885

22. Meda $\mathrm{P}(1978)$ Lysosomes in normal pancreatic beta cells. Diabetologia 14: 305-310

23. Orci L, Stauffacher W, Rufener C, Lambert AE, Rouiller C, Renold AE (1971) Acid phosphatase activity in secretory granules of pancreatic beta cells of normal rats. Diabetes 20:385-388

24. Lambert AE, Kanazawa Y, Orci L, Grodsky GM (1970) Properties of isolated beta granules in suspension. In: Falkmer S, Hellman B, Taljedal I-B (eds) The structure and metabolism of pancreatic islets. Pergamon, Oxford, pp 397-405

25. Patzelt C, Labrecque AD, Duguid JR, Carroll RJ, Keim PS, Heinrickson RL, Steiner DF (1978) Detection and kinetic behaviour of preproinsulin in pancreatic islets. Proc Natl Acad Sci USA 75: 1260-1264

26. Clark JL, Steiner DF (1969) Insulin biosynthesis in the rat: demonstration of two proinsulins. Proc Natl Acad Sci USA 62: $278-285$

27. Reddy JK, Reddy MK, Hansen LJ, Quershi SA (1980) Secretion granules of a transplantable pancreatic acinar carcinoma. Biochem J 188: 921-924

28. Hutton JC, Peshavaria M (1982) Proton-translocating $\mathrm{Mg}^{2+}-\mathrm{ATP}-$ ase activity in the insulin secretory granule. Biochem J 204: $161-170$

29. Hutton JC (1982) The internal $\mathrm{pH}$ and membrane potential of the insulin secretory granule. Biochem J 204: 171-178

30. Herman L, Sato T, Hales CN (1973) The electron microscopic localisation of cations to pancreatic islets of Langerhans and their possible role in insulin secretion. J Ultrastruct Res 42: 298-311

31. Ekholm R, Ericson LE, Lundquist I (1971) Monoamines in the pancreatic islets of the mouse: subcellular localisation of 5-hydroxytryptamine by electron microscopic autoradiography. Diabetologia 7: $339-348$

32. Abbs MT, Phillips JH (1980) Organisation of the proteins of the chromaffin granule membrane. Biochim Biophys Acta 595: 200-221

Received: 26 January 1982

and in revised form: 2 June 1982

Dr. J.C. Hutton

Department of Clinical Biochemistry

Addenbrookes Hospital

Hills Road

Cambridge CB2 2QR

UK 